\title{
A responsabilidade civil do
}

\section{Estado e o princípio da confiança} legítima*

\author{
Liability of the State and \\ the principle of legitimate \\ expectations
}

\author{
Guilherme Carvalho e Sousa**
}

\section{RESUMO}

A quebra da proteção da confiança, legitimamente depositada pelo administrado, em atos oriundos da administração pública, os quais são, inadvertidamente, modificados, causa instabilidade no sistema jurídico, ferindo os princípios da segurança jurídica, confiança legítima e boa-fé subjetiva, e ocasiona, para o Estado, o dever de responder por sua conduta, o que caracteriza responsabilidade civil do Estado perante o particular lesionado.

\section{PALAVRAS-CHAVE}

Responsabilidade civil do Estado - confiança legítima - segurança jurídica - boa-fé subjetiva

\footnotetext{
* Artigo recebido em março de 2011 e aprovado em abril de 2011.

** Procurador do estado do Amapá com lotação em Brasília. Mestrando em direito e políticas públicas pelo Uniceub - DF. Professor das disciplinas Direito Administrativo e Processo Civil do Iesb - DF. Professor de Pós-Graduação em Direito do Iesb - DF e Ceap - AP. Bacharel em direito e administração de empresas. Advogado militante.
} 


\section{ABSTRACT}

The breakage of the trust protection, legitimately given by manager in the acts from in Public Administration, which one are inadvertently modified, makes the legal system unstable, injuring the principles of legal certainty, lawful credit and belief subjective good faith, and It and causes to State the obligation to answer for their conduct, that features the civil liability of State before the particular injured.

\section{KEY-WORDS}

Civil liability of the State - legitimate expectations - legal certainty subjective good faith

\section{Introdução}

Pretende-se abordar, no presente trabalho, a responsabilidade civil do Estado pela quebra do dever de confiança legitimamente depositada, pelo administrado, nos atos emitidos pela administração pública. Não raramente, a administração pública emite atos jurídicos, seja na forma de ato administrativo, seja por meio de lei, formando promessas firmes, feitas por seus agentes, no exercício do poder administrativo, aos particulares.

Ulteriormente, a administração, de forma desavisada, modifica o planejamento ou promessa já realizada, sem garantia de transitoriedade, frustrando, no particular, que, legitimamente, agira de acordo com a orientação administrativa, uma expectativa que fora depositada na administração. Por conta disso, deve o Estado responder pelos atos que causou ao particular pela quebra do dever de confiança legitimamente depositada na administração.

Assim, abordar-se-á, num primeiro momento, a conceituação dos princípios da segurança jurídica e da boa-fé subjetiva, analisando-os, paralelamente, com o princípio da confiança legítima, a fim de que as semelhanças e diferenças entre esses institutos possam ser contempladas.

Logo após, será abordada a responsabilidade civil do Estado, fazendo-se uma breve análise sobre as diversas modalidades de responsabilidade, e enfocando o modelo que, atualmente, é adotado no Brasil, no propósito de ponderar a possibilidade de enquadramento de responsabilização pela quebra do dever de confiança no sistema brasileiro. 
Por fim, adentrar-se-á, especificamente, na responsabilidade do Estado pela quebra do dever de confiança, verificando suas reais possibilidades de ocorrência no âmbito do direito brasileiro, salientando, desde já, que não se faz possível, por questões metodológicas, a menção e consequentes comentários a julgados, tanto os do direito brasileiro, que são raros e escassos, quanto os do direito comparado.

\section{Quanto ao princípio da segurança jurídica}

Não se vislumbra, nesse debate, tecer maiores considerações sobre a segurança jurídica. Seu estudo visa, apropriadamente, a uma análise comparativa com o tema que será avaliado: a confiança legítima. É que, para a correta análise da confiança, o estudo do princípio da segurança jurídica demonstrase, invariavelmente, imprescindível, seja pela semelhança dos institutos, seja pela decorrência principiológica que a proteção à confiança adquire do princípio da segurança jurídica.

Pois bem. As raízes do conceito de segurança jurídica estão fincadas nos ideais da Revolução Francesa. Visava-se ultrapassar os juízes sumários e de probabilidade que existiam antes dessa revolução. A imensa desconfiança na magistratura, juntamente com a busca pela certeza do direito, influenciaram a robustez desse princípio como ícone do Estado liberal.

Com efeito, foi na Idade Contemporânea que a questão da segurança no direito veio à baila com toda força. Os regimes totalitaristas como o fascismo e o nazismo mostraram ao mundo que era perfeitamente possível a formação de sociedades desiguais e racistas com respaldo não só legal, mas constitucional. ${ }^{1}$

A ideia de segurança jurídica é decorrência do próprio estado de direito e corolário máximo do princípio da legalidade. Ao lado da legalidade, é um dos subprincípios integrantes desse Estado.

A segurança jurídica pode ser visualizada como um valor transcendente ao ordenamento jurídico, no sentido de que a sua investigação não

\footnotetext{
${ }^{1}$ VAINER, Bruno Zilberman. Aspectos básicos da segurança jurídica. Revista de Direito Constitucional e Internacional, ano 14, n. 56, p. 14, jul./set. 2006.
} 
se confina ao sistema jurídico positivo. Antes inspira as normas que, no âmbito do direito positivo, lhe atribuem efetividade. Matéria a ser abordada pela Filosofia do Direito. Sob essa perspectiva, a investigação filosófico-jurídica incide sob a ordenação jurídica positiva. Não coincide porém com ela. Porque a esta última só interessa a segurança jurídica enquanto valor imanente ao ordenamento jurídico. De conseguinte, a segurança jurídica é, sob este último aspecto, matéria de direito posto. Valor contemplado e consignado em normas de direito positivo. ${ }^{2}$

A Constituição de 1988, embora não tenha inserido a fórmula expressa "segurança jurídica" em seu texto, mencionou, em diversas partes, ideias de valores e de princípios relacionados à segurança. Ora, logo no preâmbulo, verifica-se essa intenção do constituinte, quando menciona estarem os representantes do povo brasileiro reunidos, em Assembleia Constituinte, para instituir um estado democrático, destinado a assegurar o exercício de direitos sociais e individuais, como também a segurança, a justiça, todas como valores supremos.

Ainda que presente, no ordenamento jurídico brasileiro, com força constitucional, o princípio da segurança jurídica, apenas recentemente, passou a ser mencionado nos livros de direito administrativo entre os princípios da administração pública. A Lei no 9.784, de 29 de janeiro de 1999, que regula o processo administrativo no âmbito da administração pública federal, menciona, em seu art. 2ํㅡㄴ caput, que a administração pública brasileira obedecerá, entre outros, ao princípio da segurança jurídica.

Pode-se entender por segurança jurídica um mínimo de estabilidade das relações sociais. É por intermédio da segurança que se garante a manutenção da paz social, viabilizando a existência de um estado democrático. Os valores segurança e justiça, como fundamentais em direito, são imprescindíveis num Estado que se diz "de direito", e, também, que se pretende "democrático".

"O conceito de segurança jurídica é considerado conquista especial do Estado de Direito. Sua função é a de proteger o indivíduo de atos arbitrários do poder estatal, já que as intervenções do Estado no direito dos cidadãos podem ser muito pesadas e, às vezes, injustas". ${ }^{3}$

\footnotetext{
${ }^{2}$ BORGES, José Souto Maior. O princípio da segurança jurídica na criação e aplicação do tributo. Revista Diálogo Jurídico, Salvador, n. 11, p. 1, fev. 2002.

${ }^{3}$ STEIN, Torstein. A segurança jurídica na ordem legal da República Federal da Alemanha. Cadernos Adenauer, Rio de Janeiro, n. 3, 2000. (Acesso à Justiça e Cidadania. Fundação Konrad Adenauer Stiftung).
} 
Por outras palavras, "ainda que seja difícil defini-lo em todas as suas dimensões, trata-se daquele princípio que elimina surpresas, desvios de entendimentos já consagrados, alteração brusca e injustificada das regras do jogo, desrespeito a decisões já tomadas". ${ }^{4}$ A segurança jurídica alcança patamares filosóficos. Ela é inerente não somente às relações mantidas com o poder público, mas também às existentes entre os particulares, muito embora priorize-se, no presente trabalho, o estudo do aludido princípio à luz das relações mantidas com o poder público.

A ideia de segurança é inseparável da própria natureza humana. Os indivíduos anseiam um mínimo de estabilidade em suas relações. Tal estabilidade deve advir, principalmente, da lei, como de regra deve acontecer em um estado de direito, como o Brasil.

O princípio visa a assegurar uma certa previsibilidade nas ações estatais, garantindo, também, o respeito pelas situações constituídas no mesmo sentido das normas impostas ou reconhecidas pelo poder público, de modo a determinar a estabilidade das relações jurídicas. É princípio de proteção ao particular face à arbitrariedade do Estado. Isso porque, no ordenamento jurídico brasileiro, só o Estado tem o poder de limitar coercitivamente direitos e garantias individuais. ${ }^{5}$

Os tribunais brasileiros, sobremaneira o Supremo Tribunal Federal, já possuem entendimento consolidado no sentido de proteção à segurança jurídica. O princípio pode ser entendido como a confiança que os cidadãos podem ter na observância e respeito de situações derivadas da aplicação de normas válidas e vigentes.

A ideia de segurança jurídica torna imperativa a adoção de cláusulas de transição nos casos de mudança radical de um dado instituto ou estatuto jurídico.

Daí porque se considera, em muitos sistemas jurídicos, que, em casos de mudança de regime jurídico, a não adoção de cláusulas de transição poderá configurar omissão legislativa inconstitucional grave.

\footnotetext{
${ }^{4}$ OLIVEIRA, Fernando Albino de. Os tribunais e o princípio da segurança jurídica. Revista Consulex, Brasília, ano 12, n. 265, p. 57, 31 jan. 2008.

${ }^{5}$ GUERRA, Evandro Martins; MIARI, Áira Lages. O processo administrativo e o princípio da segurança jurídica. Fórum Administrativo. Direito Público - F.A., Belo Horizonte, ano 6, n. 59, p. 6674, jan. 2006.
} 
$[\ldots]$

Nesse contexto assume relevância o debate sobre a anulação de atos administrativos, em decorrência de sua eventual ilicitude. Igualmente relevante se afigura a controvérsia sobre a legitimidade ou não da revogação de certos atos da Administração após transcorrido determinado prazo.

Em geral, associam-se aqui elementos de variada ordem ligados à boafé da pessoa afetada pela medida, a confiança depositada na inalterabilidade da situação e o decurso de tempo razoável. ${ }^{6}$

Por ora, antes de adentrar no estudo da confiança legítima propriamente dita, vale mencionar algumas considerações sobre o princípio da boa fé, mais especificadamente em seu aspecto subjetivo.

É que, não custa relembrar: as nuances que envolvem os conceitos de segurança jurídica, boa-fé e proteção à confiança ainda não se encontram perfeitamente definidas, carecendo de aprofundamentos mais precisos, no intuito de que se possa, ainda que por mera pretensão, galgar uma conceituação do instituto sobre o qual se trava esse debate: a proteção à confiança legítima.

\section{A boa-fé nas relações jurídicas}

No direito romano, a ideia de boa-fé era representada pela palavra fides. Objetivamente, boa-fé indica lealdade, franqueza, sinceridade. Boa-fé nada mais é do que um padrão objetivo de comportamento, decorrente da veracidade das declarações e exatidão dos comportamentos das partes - inclusive da administração - , sendo uma condição essencial a toda relação jurídica.

Enquanto a boa-fé objetiva traduz, de imediato, uma regra de comportamento, "a boa-fé subjetiva é uma qualidade reportada ao sujeito". ${ }^{7}$ A boa-fé subjetiva pode ser vista como a não consciência do injusto, dizendo respeito a substâncias psicológicas internas do agente. "Mas não há dúvida de que o conceito de boa-fé abrange também um sentido subjetivo, que equivale à

\footnotetext{
${ }^{6}$ MENDES, Gilmar Ferreira; COELHO, Inocêncio Mártires; BRANCO, Paulo Gustavo Gonet. Curso de direito constitucional. São Paulo: Saraiva, 2007. p. 473.

${ }^{7}$ MENEZES CORDEIRO, António Manuel da Rocha e. Da boa-fé no direito civil. Coimbra: Almedina, 2001. p. 407. (Teses)
} 
crença do agente de que está agindo corretamente; ele atua de determinada maneira porque desconhece toda a situação, todos os fatos e acredita que a sua conduta é a correta". ${ }^{8}$

É curial tencionar a aproximação havida entre a proteção à confiança - tema que será tratado logo em seguida - e a boa-fé. Não obstante opiniões que sustentem a igualdade de significação entre os institutos, ${ }^{9}$ a opinião que se esteia é a de que há diferenciação entre os conceitos. Todavia,

Na tarefa de diferenciá-los não se pode admitir, por superficial, a segregação que assevera, simplesmente, que a boa-fé seria um princípio aplicável tão somente no âmbito do Direito Privado, restando uma outra construção teórica - proteção da confiança - para quando se tratasse de relações jurídicas em que o Estado se faz presente..$^{10}$

A professora Maria Sylvia, embora reconhecendo a dificuldade na distinção dos nomes, segue o mesmo entendimento acima esposado, de que há diferenças nos conceitos de boa-fé e confiança legítima:

Como se distingue o princípio da boa-fé do princípio da confiança legítima?

$[\ldots]$

Na realidade, não existe uma identidade absoluta, ainda que muitas vezes seja difícil a distinção. Talvez se possa dizer que o princípio da boa-fé deve estar presente do lado da Administração e do lado do administrado. Ambos devem agir com lealdade, com correção. O princípio da proteção à confiança protege a boa-fé do administrado; por outras palavras, a confiança que se protege é aquela que o particular

\footnotetext{
${ }^{8}$ DI PIETRO, Maria Sylvia Zanella. Os princípios da proteção à confiança, da segurança jurídica e da boa-fé na anulação do ato administrativo. Fórum Administrativo. Direito Público - F.A., Belo Horizonte, ano 9, n. 100, p. 158, jun. 2009.

${ }^{9}$ Nesse sentido, "Para compreender a magnitude do problema, chamamos a atenção para o fato de que, nos poucos trabalhos sobre o assunto, sem muito esforço, encontramos opiniões que vão desde considerar a confiança como decorrência do princípio da boa-fé, a opiniões de que o princípio da boa-fé é que seria uma decorrência do princípio da confiança, e mesmo a opinião, aqui defendida, de que boa-fé e confiança são princípios da mesma hierarquia". (grifou-se). MARTINS, Raphael Magalhães. O princípio da confiança legítima e o enunciado n. 362 da IV Jornada de direito civil. Revista CEJ, Brasília, ano 12, n. 40, p. 15, jan./mar. 2008.

${ }^{10}$ MAFFINI, Rafael da Cás. Princípio da proteção substancial da confiança no direito administrativo brasileiro. Tese (doutorado) - Faculdade de Direito, Universidade Federal do Rio Grande do Sul, Porto Alegre, 2005. p. 53.
} 
deposita na Administração. O particular confia em que a conduta da Administração esteja correta, de acordo com a lei e o direito. Daí a possibilidade de manter atos ilegais ou de regular os efeitos pretéritos de atos inválidos. ${ }^{11}$

Ainda que se considere que a ideia de confiança legítima está mais afeita às relações em que o Estado se faz presente, enquadrando a boa-fé nas relações de caráter, nitidamente, privado, mesmo por esse ângulo já se faz perceber alguma diferença, muito embora seja possível afirmar que "o princípio da proteção da confiança e o princípio da boa-fé imbricam-se, numa necessária confluência para um estado de lealdade a se exigir tanto da Administração Pública quanto daqueles que são os destinatários de sua função", ${ }^{12}$ evitando o abuso de direito e o exercício antissocial deste.

\section{O princípio da proteção à confiança legítima}

A palavra confiança apresenta diversas acepções. Confiar é ter esperança em sentido positivo. É a necessidade de eliminação de incertezas, não significando inconsequências não desejadas. Segundo Raphael Martins, ${ }^{13}$ confiar nada mais é do que uma necessidade social, pois o ser humano precisa eliminar algumas das possibilidades que lhes são diuturnamente oferecidas, para reduzir a complexidade social e permitir uma intervenção mais eficaz em suas redes de relações.

Mesmo que se almejem diferenciações mais especificadas, a confiança nada mais é que o reflexo da boa-fé subjetiva. Pondera-se com a salvaguarda do interesse geral, com a proporcionalidade, com o respeito ao ato próprio, à segurança jurídica, ao estado de direito, apresentando-se como decorrência desses dois últimos. Segundo Marcelo Losso, no âmbito do direito, pode-se dizer que a confiança é um valor jurídico como a ordem, o bem comum, o interesse social e a segurança, entre outros, que o ordenamento jurídico busca preservar. $^{14}$

\footnotetext{
${ }^{11}$ Di Pietro, Os princípios da proteção à confiança..., op. cit., p. 159.

${ }^{12}$ Maffini, Princípio da proteção substancial da confiança..., op. cit., p. 56.

${ }^{13}$ Martins, O princípio da confiança legítima..., op. cit., p. 12.

${ }^{14}$ LOSSO, Marcelo Ribeiro. O princípio da proteção à confiança nas relações contratuais entre o Estado e o agente privado. Dissertação (mestrado) - Direito Econômico e Social, Pontifícia Universidade Católica do Paraná, Curitiba, 2008.
} 
De qualquer forma, em qualquer das perspectivas pelas quais se possa analisar o sobreprincípio do Estado de Direito, afigura-se uma constante a menção à segurança jurídica, no sentido de que este (o princípio da segurança jurídica) decorre, dedutivamente, daquele (o sobreprincípio do Estado de Direito). ${ }^{15}$

Embora os temas se aproximem, não é satisfatório confundir proteção à confiança com boa-fé, igualmente não se lhe podendo emprestar o mesmo significado que é dado ao princípio da segurança jurídica. A proteção da confiança possui delineamento próprio, cujas amarras estão voltadas para as relações mantidas com o poder público.

De esta forma, mientras que el principio de seguridad jurídica stricto sensu exige que las actuaciones públicas se adecúen a una regla objetiva de seguridad (estabilidad de regulaciones y de situaciones jurídicas), el principio de confianza legítima tiene por objeto proteger la confianza que los destinatarios de aquellas actuaciones pueden tener en la estabilidad, al menos por un cierto tiempo, de las situaciones establecidas sobre la base de dichas reglas. Así, el principio de seguridad sensu stricto puede ser aplicado de forma abstracta (sin tener en cuenta la situación concreta de los administrados), mientras que el de confianza sólo puede aplicarse a la luz de la situación concreta e de la actitud - buena fe, compromisos, intervesiones - de los interesados. ${ }^{16}$

Tal princípio originou-se no ordenamento alemão. Segundo Javier Garcia Luengo, ${ }^{17}$ o primeiro caso analisado pelo Superior Tribunal Administrativo de Berlim ocorreu em 1956. Tratava-se de um funcionário público que obteve, mediante ato administrativo, promessa de que, caso se transferisse de Berlim Oriental para Berlim Ocidental, teria sua pensão normalmente paga. Após se mudar e passar a receber a pensão, as autoridades perceberam que houve vício de competência, retirando-lhe o benefício, além de determinar a devolução dos valores já pagos.

\footnotetext{
${ }^{15}$ Maffini, Princípio da proteção substancial da confiança..., op. cit., p. 37.

${ }^{16}$ SANZ RUBIALES, Iñigo. El principio de confianza legítima, limitador del poder normativo comunitario. Disponível em: <www.cepc.es/rap/Publicaciones/Revistas/4/RDC_007_091.pdf>. Acesso em: 26 fev. 2011. p. 100-101.

${ }^{17}$ GARCIA LUENGO, Javier. El principio de protección de la confianza en el derecho administrativo. Madri: Civitas, 2002.
} 
Precisas as lições de Almiro do Couto e Silva, ${ }^{18}$ a quem se reputam, no Brasil, os estudos iniciais do princípio da proteção à confiança legítima. Segundo o autor, foi no século XX que o princípio da proteção à confiança ganhou mais nitidez, destacando-se da segurança jurídica, tendo notável expansão na Europa, onde conquistou sucesso retumbante.

Salienta o doutrinador gaúcho que o princípio nasceu na Alemanha, por construção jurisprudencial, prendendo-se, predominantemente, à questão de atos inválidos, nos quais existia indiscutível boa-fé. Primeiro, firmou-se a partir de decisão do Superior Tribunal Administrativo de Berlim, em 1956, sendo seguido por acórdão do Tribunal Administrativo Federal (BverwGE), de 15 de outubro de 1957, e, consequentemente, gerando uma corrente contínua de manifestações jurisprudenciais no mesmo sentido, até se consolidar com sua inserção na Lei de Processo Administrativo alemã, de 1976, cujo § 48 dispôs sobre a aplicação do mencionado princípio. E já na década de 1970 ocorreu o reconhecimento, pelo Tribunal Federal Constitucional, da proteção à confiança como princípio de valor constitucional.

Após sua solidificação no direito alemão, o princípio ingressou no direito da União Europeia, consagrando-se em decisões da Corte de Justiça das Comunidades Europeias como regra superior de direito e princípio fundamental do direito comunitário. ${ }^{19}$

"No direito brasileiro o tema demorou a ser tratado, talvez pelo fato de que as nossas Constituições (ao contrário das europeias) têm consagrado o princípio da proteção ao direito adquirido, à coisa julgada e ao ato jurídico perfeito, que constituem aplicação do princípio da segurança jurídica." ${ }^{20}$ É que, no Brasil, "não houve grande preocupação na identificação da segurança jurídica, vista pelo ângulo subjetivo da proteção à confiança, como princípio constitucional, situado no mesmo plano de importância do princípio da legalidade" ${ }^{21}$

Muito embora a jurisprudência seja tímida nesse sentido, ${ }^{22}$ sendo escassas as decisões ${ }^{23}$ que tratem do aludido princípio, já existem julgados do Su-

\footnotetext{
${ }^{18}$ SILVA, Almiro do Couto e. O princípio da segurança jurídica (proteção à confiança) no direito público brasileiro e o direito da administração pública de anular seus próprios atos administrativos: o prazo decadencial do art. 54 da Lei de Processo Administrativo da União. Lei no 9.784/99. Revista Brasileira de Direito Público - RBDP, Belo Horizonte, ano 2, n. 6, p. 11-12, jul./set. 2004. ${ }^{19}$ Ibid.

${ }^{20}$ Di Pietro, Os princípios da proteção à confiança..., op. cit., p. 157.

${ }^{21}$ Silva, O princípio da segurança jurídica..., op. cit., p. 15.

${ }^{22}$ Não é prescindível mencionar que, no julgamento do Recurso Extraordinário no 85.179/RJ, da lavra do então presidente do STF, Bilac Pinto, a corte constitucional já imprimiu valores maiores ao princípio da segurança jurídica.

${ }^{23}$ Não será possível analisar, detidamente, as decisões judiciais que tratam do princípio da confiança legítima, uma vez que o espaço e o propósito deste trabalho não permitem.
} 
premo Tribunal Federal e do Superior Tribunal de Justiça aflorando uma nova forma de pensar da administração, alçando a confiança legítima e a segurança jurídica a patamares mais elevados. ${ }^{24}$

Tal princípio finca-se nas noções de previsibilidade e estabilidade, podendo ser visto com envergadura constitucional - em sentido material ${ }^{25}-$, muito embora não esteja previsto, formalmente, no texto da Constituição de 1988. "No direito brasileiro não há previsão expressa do princípio da proteção à confiança; pelo menos não com essa designação, o que não significa que ele não decorra implicitamente do ordenamento jurídico." ${ }^{26}$

O princípio deve ser ponderado não apenas nos casos de dar proteção à existência de direitos adquiridos, mas também pela frustração de simples expectativas, que se vejam truncadas por modificações normativas. É importante tencionar que, pelo menos para o presente caso, e com o objetivo de se manter fiel ao tema proposto, o estudo da proteção da confiança será mantido, unicamente, na moldura do direito administrativo, não se lhe conferindo a análise na seara privada.

Objetiva-se, com isso, deduzir quais são as relações e possíveis consequências que podem advir com a edição de um ato administrativo que gere expectativas no administrado e que, posteriormente, venha a ser retirado do mundo jurídico. Segundo Soren Schonberg, ${ }^{27}$ a proteção da confiança pode ser verificada com base em três perspectivas, ${ }^{28}$ entre as quais a proteção compensatória da confiança, é dizer, o dever do Estado de ressarcir os prejuízos decorrentes da frustração de expectativas nele legitimamente depositadas pelos cidadãos.

\footnotetext{
${ }^{24}$ Nesse sentido, BRASIL. Supremo Tribunal Federal. MC nํำ 2.900-RS. 2 Turma, relator ministro Gilmar Mendes. 8 mar. 2003. Disponível em: <www.stf.jus.br>. Acesso em: 26 fev. 2011. BRASIL. Supremo Tribunal Federal. Informativo do STF. Relator ministro Gilmar Mendes n. 231, MS 24268/MG, 15 mar. 2003. Disponível em: <www.stf.jus.br//arquivo/informativo/documento/informativo231.htm>. Acesso em: 26 fev. 2011. Ainda no mesmo sentido, BRASIL. Superior Tribunal de Justiça. REsp. 141.879. 4⿳一巛工 Turma, relator ministro Ruy Rosado de Aguiar. 7 mar. 1998. Disponível em: <www.stj.jus.br>. Acesso em: 26 fev. 2011.

${ }^{25}$ Adota-se a distinção feita pelo doutrinador português Jorge de Miranda, para quem "todos os direitos fundamentais em sentido formal são também direitos fundamentais em sentido material. Mas há direitos fundamentais em sentido material para além deles". MIRANDA, Jorge. Manual de direito constitucional: direitos fundamentais. 3. ed. Coimbra: Coimbra, 2000. t. 4, p. 9.

${ }^{26}$ Di Pietro, Os princípios da proteção à confiança..., op .cit., p. 158.

27 SCHONBERG, Soren J. Legitimate expectations in administrative law. Oxford: Oxford, 2000. p. 31-59.

${ }^{28}$ As outras perspectivas traçadas pelo autor - proteção procedimental e proteção substancial da confiança -, muito embora de reconhecida relevância, perdem sentido para o presente trabalho, eis que, para esse ensaio, interessa o aspecto indenizatório, decorrente da responsabilização do Estado.
} 
O Estado, ao editar atos, e, portanto, formar relação com particulares, deve se ater aos ditames da boa-fé daqueles que nele depositaram suas legítimas confianças. Esse entendimento escora-se no ideário do atual estado de direito.

Na verdade, a subordinação de todos os poderes à ideia de Direito já contém em si a carga normativa que este princípio encerra. Mais concretamente, no conteúdo do princípio da confiança, ínsito a qualquer Estado de Direito genuíno. O conteúdo deste princípio jurídico fundamental comporta várias dimensões, sendo que uma das possíveis é, sem dúvida, a ideia de boa-fé. ${ }^{29}$

A supremacia do interesse público ${ }^{30}$ não justifica a quebra da boa-fé do particular perante a administração pública. A administração, ao agir - e assim o faz, geralmente, com a prática de atos administrativos, como também por meio de atos legislativos - cria, no mundo jurídico (o universo da administração), direitos e obrigações, tanto para si como também para os administrados. É que:

[...] a figura do ato administrativo continua a ser o mais importante instrumento para a prossecução do interesse público e, no quadro da moderna Administração de prestação, de rápida e estável definição das situações jurídicas, no interesse da segurança jurídica e, em especial, da confiança dos interessados na constituição de posições de vantagens. ${ }^{31}$

Editando atos administrativos presumivelmente legítimos e válidos, a administração pública faz transparecer um modo de agir, direcionando uma conduta que o administrado, por crer no ato da administração, reputa ser a correta e a que deve ser seguida. Os princípios da legalidade e da supremacia

\footnotetext{
${ }^{29}$ CARVALHO, Raquel. O direito à informação administrativa procedimental. Porto: Universidade Católica, 1999. p. 67.

${ }^{30}$ Sobre o tema, há interessante estudo no direito brasileiro que trata da superação da supremacia do interesse público. SARMENTO, Daniel. Interesses públicos versus interesses privados: desconstruindo o princípio da supremacia do interesse público. Rio de Janeiro: Lumen Juris, 2010.

${ }^{31}$ ALMEIDA, Mário Aroso de. Anulação de atos administrativos e relações jurídicas emergentes. Coimbra: Almedina, 2002. p. 81.
} 
do interesse público não podem ser óbices à aplicação do princípio da proteção à confiança, sob pena de um retrocesso do próprio direito administrativo, não se lhe permitindo avançar nos rumos da efetivação de uma justiça material, substantiva, em detrimento de um rigorismo formal-legalista.

É de grande importância para a Administração se desvincular de atitudes tipicamente de império, que por vezes dirigem a atividade estatal e resultam em violação às expectativas dos particulares.

$[\ldots]$

O cada vez mais frequente apelo à confiança na relação da Administração com o cidadão ressalta a insuficiência dos princípios da legalidade e da segurança para resolver os problemas do Estado de Direito. ${ }^{32}$

Em determinados casos, a administração invalida o ato em momento posterior, causando prejuízos àqueles destinatários do ato, provocando instabilidade nas relações jurídicas e desprestigiando os princípios da segurança jurídica e da proteção à confiança. Por que o Estado, nesses casos específicos, não deveria indenizar? Portanto, o princípio da proteção à confiança tem sido utilizado "como un mecanismo para armonizar y conciliar casos en que la administración en su condición de autoridad, por acción o por omisión ha creado expectativas favorables a los administrados y de forma abrupta elimina esas condiciones". ${ }^{33}$

“Na verdade, o que o direito protege não é a aparência de legitimidade daqueles atos, mas a confiança gerada nas pessoas em virtude ou por força da presunção de legalidade e da aparência de legitimidade que têm os atos do Poder Público." ${ }^{34}$ Nesse ponto, é importante perceber que, com a adequada proteção da confiança legítima, o ordenamento não apenas garante a segurança e a confiabilidade nas relações sociais, mas também, de maneira reflexa, acabando por fortalecer a própria confiança no ordenamento jurídico. É necessário, assim, proteger a confiança depositada, como meio de fortalecer o papel da autorresponsabilização dos sujeitos na relação jurídica e também a segurança jurídica, tanto nessas relações como no ordenamento.

\footnotetext{
${ }^{32}$ Losso, O princípio da proteção à confiança..., op. cit., p. 126-127, 188.

${ }^{33}$ PALACIO PALACIO, Jorge Iván. Principio de confianza legítima en la jurisprudencia de la corte constitucional. Disponível em: <http://iusconstifil.blogspot.com/2009/09/principio-de-confianzalegitima-en-la.html>. Acesso em: 26. fev. 2011.

${ }^{34}$ Silva, O princípio da segurança jurídica..., op. cit., p. 7-59.
} 
Não restam dúvidas de que o princípio presta-se a tutelar expectativas legítimas que os administrados depositaram na permanência de uma regulamentação. No entanto, não se pode falar que uma mera modificação normativa, que não cause prejuízo manifesto e efetivo ao administrado, possa ser tutelada por tal princípio. Somente tem aplicação quando determinado bem jurídico, tutelado pelo direito, e já incorporado ao patrimônio de um particular, é violado. Nesses casos, ainda que o direito tenha se inserido no patrimônio do particular de forma ilegal, deve-se sustentar a manutenção do ato que propiciou a inserção em homenagem à confiança depositada no ato.

La confianza legítima es un principio constitucional que directa o indirectamente está en cabeza de todos los administrados lo cual obliga al Estado a procurar su garantía y protección. Es un mandato inspirado y retroalimentado por el de la buena fe y otros, que consiste en que la administración no puede repentinamente cambiar unas condiciones que directa o indirectamente permitía a los administrados, sin que se otorgue un período razonable de transición o una solución para los problemas derivados de su acción u omisión. Dentro del alcance y límites es relevante tener en cuenta, según el caso concreto: (i) que no libera a la administración del deber de enderezar sus actos u omisiones irregulares, sino que le impone la obligación de hacerlo de manera tal que no se atropellen los derechos fundamentales de los asociados, para lo cual será preciso examinar cautelosamente el impacto de su proceder y diseñar estrategias de solución; (ii) que no se trata de un derecho absoluto y por tanto su ponderación debe efectuarse bajo el criterio de proporcionalidad; (iii) que no puede estar enfocado a obtener el pago de indemnización, resarcimiento, reparación, donación o semejantes y (iv) que no recae sobre derechos adquiridos, sino de situaciones jurídicas anómalas susceptibles de modificación. ${ }^{35}$

Ademais, não se pretende, com a utilização do princípio da confiança, manter-se todo e qualquer ato no mundo jurídico. Absolutamente não. Com efeito, não existe uma vedação absoluta e irrestrita à retroatividade normativa. ${ }^{36}$ Por isso, faz-se necessário estabelecer um regime que, ao mesmo tem-

\footnotetext{
${ }^{35}$ COLOMBIA. Corte Constitucional de Colombia. Sentencia T-472/09. Accion de tutela contra actuaciones de autoridades de policia. Disponível em: <www.corteconstitucional.gov.co/relatoria/2009/T-472-09.htm>. Acesso em: 26. fev. 2011.

${ }^{36}$ Essa a lição de CALMÈS, Sylvia. Du principe de protection de laconfiancelégitime em droitsallemand, communautaire et français. Paris: Dalloz, 2001.
} 
po, permita a evolução do direito sem sacrificar a esfera do particular. Nesse sentido, "o princípio da proteção da confiança serve como um instrumento de equilíbrio que torna possível a irretroatividade sem que esta, por sua vez, cause prejuízo aos interesses privados que puderem resultar afetados" ${ }^{37}$

O professor Almiro do Couto e Silva menciona, dentre os atuais temas relacionados com o princípio da segurança jurídica e da proteção da confiança, tanto no direito comparado como também no direito brasileiro, entre outros, a responsabilidade do Estado pelas promessas firmes feitas por seus agentes. ${ }^{38}$

O enfoque sobre o qual se debruça este artigo é, justamente, verificar a responsabilidade do Estado, em pós-emissão de atos jurídicos, nos quais constem promessas feitas aos administrados, garantindo-lhes direitos ou prerrogativas, os quais, posteriormente, são suprimidos inesperadamente, sem que haja lapso temporal suficiente de adaptação para o administrado.

Para tanto, a fim de que se possa aferir a responsabilidade do Estado nesses casos, é forçoso, primeiramente, uma sucinta leitura sobre o instituto da responsabilidade civil do Estado, passando por um brevíssimo transcorrer histórico, a fim de que se tenha a noção de em qual estágio encontra-se o ordenamento brasileiro; dito de outro modo, qual teoria é adotada pelo Brasil.

\section{A responsabilidade civil do Estado}

O fundamento da responsabilidade civil do Estado não é totalmente diverso do fundamento da responsabilidade civil quando se trata de particulares. O dano causado a outrem, independentemente de ser ou não ilícito, merece ser indenizado. A comunidade deve indenizar, em conformidade com os princípios gerais comuns ao ordenamento jurídico, os danos causados por suas instituições ou por seus agentes no exercício de suas funções.

O fundamento da responsabilidade do Estado é o bem comum. É dizer, o bem de toda a comunidade, e ela não pode encontrar-se plenamente satisfeita se um membro ou um grupo de seus membros sofre os danos produzidos pela atividade da administração; portanto, corresponde-lhe indenizar os prejuízos que ocasione. ${ }^{39}$

\footnotetext{
${ }^{37}$ CASTILLO BLANCO, Frederico. La protección de confianza en el derecho administrativo. Madrid: Marcial Pons, 1988. p. 198.

${ }^{38}$ Silva, O princípio da segurança jurídica..., op. cit., p. 15.

${ }^{39}$ GANDINI, João Agnaldo Donizeti. Responsabilidade do Estado em caso de falência de concessionário. Campinas: Minelli, 2003. p. 88.
} 
Difere da responsabilidade contratual e da responsabilidade legal. Refere-se ao dever de reparar os danos causados a terceiros, exaurindo-se com a indenização. "Responsabilidade civil da Administração é, pois, a que impõe à Fazenda Pública a obrigação de compor o dano causado a terceiros por agentes públicos no desempenho de suas atribuições ou a pretexto de exercê-las." ${ }^{40}$

Dito de outro modo, "entende-se a responsabilidade civil do Estado como sendo a obrigação legal que lhe é imposta, de ressarcir os danos causados por suas atividades a terceiros". ${ }^{41}$

La responsabilidad extracontractual del Estado se traduce en la búsqueda de soluciones tendientes a otorgar a los ciudadanos una adecuada protección legal frente a los daños sufridos en su persona o propiedad derivados de la actividad jurídica y material de la Administración y del Estado en general. ${ }^{42}$

A responsabilidade civil do Estado passou por várias fases. ${ }^{43}$ Da total irresponsabilidade, em que não se cogitava da responsabilização do Estado (Le roi ne peut mal faire; The king can do notwrong), encontra-se hoje na fase da responsabilidade objetiva, adotando a teoria do risco administrativo, em que a demonstração da culpa é desnecessária.

A teoria da irresponsabilidade logo foi ultrapassada pela teoria civilista e suas derivações, com a propalada divisão entre atos de império e atos de gestão. Na verdade, agindo o Estado no exercício de sua soberania, praticando atos de império, estaria isento de responsabilização; por outro lado, na prática dos atos de gestão, responderia da mesma forma que as empresas privadas (princípios civilísticos de responsabilização por fatos de terceiros), pelos atos de seus agentes ou prepostos. Já na terceira e última fase da evolução da responsabilização, insere-se uma concepção publicística "e a questão se desabrocha e se desenvolve no terreno próprio do direito público, pretendendo-se desvinculada de todo apoio tomado do direito civil". ${ }^{4}$

\footnotetext{
${ }^{40}$ MEIRELLES, Hely Lopes. Direito administrativo brasileiro. 36. ed. São Paulo: Malheiros, 2010. p. 680 .

${ }^{41}$ CAHALI, Yussef Said. Responsabilidade civil do Estado. São Paulo: Revista dos Tribunais. 1982. p. 1.

${ }^{42}$ CERDA, Clara Leonora Szczaranski. Responsabilidad extracontractual del Estado. Revista de Derecho - Derecho Administrativo, n. 8, p. 1, ago. 2003. Disponível em: <www.cde.cl/wps/wcm/ connect/.../2.pdf?MOD=AJPERES>. Acesso em: 14 fev. 2011.

${ }^{43}$ Não será feito um detalhamento aprofundado das fases pelas quais passou a teoria da responsabilidade do Estado, uma vez que o propósito contido neste trabalho é, especificamente, tencionar, em seu atual estágio, a responsabilidade pela quebra do dever de confiança.

${ }^{44}$ Cahali, Responsabilidade civil do Estado, op. cit., p. 14.
} 
Uma vez proclamada a responsabilidade objetiva do Estado, esta não mais se baseia nos critérios preconizados pelo direito civil. Fincada nos princípios da equidade, da igualdade de ônus e dos encargos sociais, a responsabilidade do Estado passa a se encravar, decisivamente, no campo do direito público.

A tese da culpa administrativa, muito embora tenha sido uma fase de transição entre a teoria subjetiva da culpa civil e a teoria do risco administrativo, que a sucedeu, teve sua importância, uma vez que estabeleceu o binômio falta do serviço/culpa da administração como suficiente para a responsabilização do Estado. No entanto, não se desvencilhou das amarras da culpa como suficiente para provocar a indenização. Já a teoria do risco administrativo alijouse da ideia de culpa, atendo-se, apenas, ao dano, não exigindo a comprovação da falta do serviço público, nem muito menos da culpa de seus agentes..$^{45}$

A teoria adotada pelo ordenamento brasileiro foi a do risco administrativo. Analiticamente, não se discute a culpabilidade da conduta causadora do dano, mas, apenas, o dano em si, muito embora seja permitido à administração provar a culpa da vítima (total ou parcial), excluindo ou atenuando a indenização. Trata-se de uma responsabilidade, nitidamente, objetiva. "Responsabilidade objetiva é a obrigação de indenizar que incumbe a alguém em razão de um procedimento lícito ou ilícito que produziu uma lesão na esfera juridicamente protegida de outrem. Para configurá-la basta, pois, a mera relação causal entre o comportamento e o dano" ${ }^{46}$

Da mesma forma, não se perquire se a atividade que deflagra o dano é justa ou injusta.

Até mesmo nas atividades desenvolvidas legitimamente pelo Estado, v.g., execução compulsória de medidas sanitárias, caso haja danos injustos, há o dever de indenizar, ainda que seja uma atividade lícita. Essa teoria foi acolhida no ordenamento brasileiro, encontrando amparo na regra inserta no art. $37, \S 6^{\circ}$ do texto constitucional, o qual leciona:

\section{Art. 37. Omissis}

$\S 6^{0}-$ As pessoas jurídicas de direito público e as de direito privado prestadoras de serviços públicos responderão pelos danos que seus

\footnotetext{
${ }^{45}$ Cumpre ressaltar que a teoria do risco integral, modalidade extremada do risco administrativo, pela qual a administração ficaria obrigada a indenizar todo e qualquer dano suportado por terceiros, ainda que resultante de culpa ou dolo da vítima, não foi acolhida no direito pátrio.

${ }^{46}$ BANDEIRA DE MELLO, Celso Antônio. Curso de direito administrativo. 16. ed. São Paulo: Malheiros. 2003. p. 864-865.
} 
agentes, nessa qualidade, causarem a terceiros, assegurado o direito de regresso contra o responsável nos casos de dolo ou culpa. ${ }^{47}$

A Constituição Brasileira de 1988 adotou a responsabilidade objetiva na modalidade do risco administrativo, em que não se perquire a culpa, atendo-se ao dano, "o que envolve considerações sobre a obrigatoriedade de reparação mesmo no caso de ato legítimo, mas danoso, assim como nas hipóteses de atos praticados de acordo com as leis e regulamentos, ou seja, do ato ilícito" ${ }^{48}$

Ao contrário da teoria da culpa administrativa, fundada na ação ou omissão do homem, a teoria do risco baseia-se no princípio da causalidade. "A causalidade tem a sua explicação natural e fácil no princípio da representação, segundo a qual, o Estado é a causa eficiente do ato lesivo, por tê-lo querido e praticado pelo seu funcionário ou representante" ${ }^{49}$ A indenizabilidade não advém, necessariamente, da ilicitude da conduta. Muito embora se esteja diante da liceidade de determinado agir ou omitir, ainda assim se pode falar no dever de indenizar, forte na causalidade, eis que interessa o dano. É que, "se todo ato ilícito, em sendo danoso, implica a obrigação de reparar para o responsável, seja ele o agente (responsabilidade subjetiva) ou não (responsabilidade transubjetiva), nem toda obrigação de reparar provém do ato ilícito" ${ }^{50}$

Risco administrativo não significa que a Administração deva indenizar sempre e em qualquer caso o dano suportado pelo particular; significa, apenas, e tão somente, que a vítima fica dispensada de prova da culpa da Administração, mas esta poderá demonstrar a culpa total ou parcial do lesado no evento danoso, caso em que a Fazenda Pública se eximirá total ou parcialmente da indenização. ${ }^{51}$

Feitas essas considerações, pode-se, a partir de agora, verificar como deve ser a responsabilização no caso da quebra do dever de confiança depositado, legitimamente, na administração.

\footnotetext{
${ }^{47}$ BRASIL. Constituição federal. Disponível em: <www.planalto.gov.br/ccivil_03/Constituicao/ Constituicao.htm>. Acesso em: 26 fev. 2011.

${ }^{48}$ CRETELLA JÚNIOR, José. O Estado e a obrigação de indenizar. Rio de Janeiro: Forense, 1998. p. 308.

${ }^{49}$ CAVALCANTI, Amaro. Responsabilidade civil do Estado. Rio de Janeiro: Borsoi, 1957. t.1, p. 350.

${ }^{50}$ ALVES, Vilson Rodrigues. Responsabilidade civil do Estado por atos dos agentes dos poderes Legislativo, Executivo e Judiciário. Campinas: Bookseller, 2001. t. 1, p. 61.

${ }^{51}$ Cretella Júnior, O Estado e a obrigação de indenizar, op. cit., p. 308.
} 


\section{A responsabilidade civil do Estado e o princípio da proteção da confiança}

À luz das considerações já realizadas, parece crível poder haver responsabilização do Estado nos casos em que o administrado se vê no difícil dever de, repentinamente, modificar seu proceder, o qual houvera obtido com arrimo em manifestação da vontade da administração, seja por meio de ato administrativo, seja por meio de lei, ${ }^{52}$ pois não se demonstra razoável que a administração, até então, viabilizando que o administrado mantivesse determinada conduta, pautada em ato prévio, da própria administração, modifique seu posicionamento, causando prejuízos concretos ao administrado, não tenha que responder pelo dano causado.

Todavia, não é qualquer ato estatal que ocasiona a responsabilização do Estado. Alguns requisitos devem se fazer presentes. A verificação destes pressupostos pode ser mensurada através das consequências da tutela em concreto da proteção da confiança. Socorrendo-se das lições da professora Patrícia Baptista, ${ }^{53}$ o direito comparado indica quatro consequências possíveis: a) estabelecimento de medidas transitórias ou de um período de vacatio; b) a observância do termo de vigência fixado para a norma revogada; c) a outorga de uma indenização compensatória pela frustração da confiança, e d) a exclusão do administrado da incidência da nova regulamentação.

A ausência de medidas transitórias pode constituir uma infração da confiança legítima dos particulares que, certamente, merece ser indenizada. Desde um ponto de vista temporal, há violação do ordenamento, sobremaneira de seus princípios gerais, uma vez que o conteúdo da norma, até então previsível, aflora-se imprevisível ou de difícil previsibilidade. Da mesma forma, a imprevisibilidade decorrente da não observância do termo de vigência fixado para a norma revogada.

Das consequências que podem advir da análise em concreto da proteção da confiança, para o presente trabalho, interessa a outorga de uma indenização compensatória. É aqui que incide a regra da responsabilização do Estado. Portanto, primeiro deve se observar se se trata de um caso em que pode ser

\footnotetext{
${ }^{52}$ Entendendo-se esta no sentido genérico da palavra.

${ }^{53}$ BAPTISTA, Patrícia. A tutela da confiança legítima como limite ao exercício do poder normativo da administração pública. A proteção das expectativas legítimas dos cidadãos como limite à retroatividade normativa. Revista Eletrônica de Direito do Estado - REDE, Salvador, n. 11, p. 16, jul./ago. 2007.
} 
suscitada a proteção da confiança. Em caso afirmativo, procede-se a uma segunda fase.

Nessa segunda fase de análise, verificando-se que houve respeito à transitoriedade, ou que se observou o termo de vigência fixado para a norma revogada ou mesmo que houve a exclusão do administrado da incidência da nova regulamentação, certamente, não haverá responsabilização do Estado. Há a possibilidade, também, como já visto, de o Estado proceder, desde logo, a uma indenização. Assim não agindo o Estado, a solução é a indenização.

Como já salientado, a legalidade estrita da administração pública deve ceder espaço a princípios outros, de igual modo essenciais ao estado de direito, como a segurança nas relações jurídicas, com ênfase, sobremaneira, em seu aspecto subjetivo, a proteção à confiança. A exegese da responsabilidade civil do Estado, adotando-se a teoria do risco administrativo, orienta-se, justamente, nesse sentido: promover responsabilização sempre que houver a existência dos elementos necessários e suficientes para tanto, em especial o dano.

Não há, na teoria da responsabilidade do Estado, uma forma genérica de determinação dos casos em que se deva indenizar. Em outras palavras, "no existe ninguna regla general que determine cuáles son concretamente las condiciones para que esa responsabilidad exista, pues ello depende del caso que se está considerando". ${ }^{54}$

Ora, se há dano decorrente de uma atividade estatal, ainda que lícita, mas que, por óbvio, provoque prejuízo a terceiros, tal prejuízo merece ser indenizado. Pensar de forma contrária é desafiar o sentido evolutivo inerente ao direito, espelho das modificações sociais.

Do mesmo modo que a natureza, o direito evolui progressivamente, sem ruptura, dando novas formas às instituições e modificando, eventualmente, o sentido das normas, para adaptá-las às novas necessidades sociais e econômicas. Mas mantém os princípios básicos, que datam do Direito Romano, e os valores que caracterizam a civilização ocidental e nossas tradições culturais.

A evolução do Direito pode ser considerada lenta, em virtude da sua sistemática, de um certo misoneísmo e da aparente aversão da maioria dos magistrados à inovação. [...]

\footnotetext{
${ }^{54}$ GORDILLO, Augustín. Tratado de derecho administrativo: la defesa del usuário y del administrado. 5. ed. Belo Horizonte: Del Rey, 2003. t. 1, p. XX-19.
} 
Por outro lado, em matéria jurídica, o conservadorismo não significa a defesa intransigente das posições do passado. Ao contrário, conservar significa aprimorar e reformar, pois somente com a reformulação modernizadora será garantida a sobrevivência do Estado de Direito, a boa distribuição da Justiça e a paz social, finalidades da lei e da atuação do Poder Judiciário. ${ }^{55}$

Não se pode temer ousar no direito, respeitados, obviamente, critérios mínimos que permitam enquadrar a proposta inovadora no instituto devido. Fala-se, ao menos, no preenchimento dos requisitos inerentes à responsabilidade. Assim, faz-se necessário que estejam presentes os elementos que formam a responsabilidade do Estado, ação ou omissão, dano e nexo de causalidade.

Não é, portanto, qualquer dano que ocasiona o dever de indenizar por parte do Estado. Tratando-se de uma conduta estatal previsível, cujos resultados podem acarretar riscos, previamente calculáveis, não se pode falar em indenização pela quebra do dever de confiança. É que esta deve ser depreendida, em todos os casos, de signos externos, objetivos, inequívocos, e não a deduzir subjetivamente, supondo intenções não objetiváveis.

Relevante ressaltar que essa responsabilização, em se tratando da Administração Pública, não é regra a ser indiscriminadamente invocada. A própria noção de confiança não é objetiva. Não é demais recordar que a Administração por vezes tem o dever de anular seus atos, inclusive os que precedem as contratações, e por outras se vê diante da necessidade de revogar seus atos por conta de critérios de conveniência e oportunidade. Daí a se concluir que a responsabilização da Administração deverá ser precedida de ampla análise das circunstâncias do caso e dos efeitos ao particular. ${ }^{56}$

Esses fatos externos devem ser, necessariamente, concludentes, induzindo, racionalmente, o administrado a confiar na aparência de legalidade e previsibilidade de uma atuação administrativa concreta. A proteção à confiança consoliza-se, portanto, propiciando a indenização àquele que confiou

\footnotetext{
${ }^{55}$ MARTINS, Ives Gandra da Silva. O Supremo e a segurança jurídica. Revista Consulex, Brasília, ano 11, n. 259, p. 21, 31 out. 2007.

${ }^{56}$ Losso, O princípio da proteção à confiança..., op. cit., p. 168.
} 
e teve sua confiança violada. Assim, a administração deve sopesar quais são as possíveis consequências que podem advir da utilização desajustada de seu poder de império, haja vista a obrigatoriedade do dever de indenizar, em não sendo possível a manutenção da situação jurídica criada pela própria administração.

\section{Considerações finais}

Ao lume do que foi exposto, pôde-se perceber que o princípio da proteção à confiança encontra amparo no próprio estado de direito, sendo decorrência do princípio da segurança jurídica e se alinhando aos mesmos propósitos da boa-fé subjetiva. Por mais que seja um princípio de criação recente, sobremaneira no Brasil, tendo surgido, inicialmente, na jurisprudência, já se encontra codificado em muitos ordenamentos jurídicos alienígenas, ainda que, no ordenamento brasileiro, encontre abrigo, por ora, nas decisões jurisprudenciais.

Mesmo na jurisprudência, sua incidência é incipiente, mas logo é possível perceber que o avanço na aplicação do princípio tem provocado profundas modificações nas relações jurídicas.

Por meio de seus atos, o Estado é capaz de causar prejuízos aos administrados que, legitimamente, confiaram na conduta estatal. Nestes casos, resta imperante a regra da responsabilização civil do Estado, desde que, obviamente, estejam presentes os elementos necessários para caracterizá-la: dano, ação ou omissão do agente e nexo de causalidade.

Não se pode confiar o direito público a serviço, unicamente, da administração, mas também da pessoa humana, individualmente considerada. Por isso, os princípios da supremacia do interesse público e da legalidade devem ser repensados, cedendo, por vezes, espaço à segurança das relações jurídicas, à confiança legítima e à boa-fé.

O administrado não pode ser surpreendido por uma vontade administrativa sem que se lhe oportunize, ao menos, medidas transitórias suficientes que lhe permitam acomodar sua conduta. Assim não agindo, a administração deve ser compelida a indenizar o particular lesionado.

Não se pretendeu, com a presente discussão, imprimir uma nova teoria de responsabilização pela conduta estatal. Muito pelo contrário, contemplase a mesma teoria - a do risco administrativo - e, alicerçado nela, é que se almeja the conferir um novo estágio.

Até mesmo porque, como já se salientou assaz, a teoria do risco administrativo é suficiente, por si só, para fornecer os elementos deflagradores da 
responsabilização do Estado em casos tais, muito embora a comprovação da confiança possa, por vezes, carecer de comprovação alheia à objetividade inerente a essa teoria.

Pensar de forma diversa é manter incólumes condutas estatais que, verdadeiramente, causam danos. Em assim sendo, não se imprime ao direito uma evolução progressiva, mas sim um retrocesso demasiado, cujas amarras podem se prender à já extinta teoria da irresponsabilidade do Estado, o que não é desejável, por evidente.

\section{Referências}

ALMEIDA, Mário Aroso de. Anulação de atos administrativos e relações jurídicas emergentes. Coimbra: Almedina, 2002.

ALVES, Vilson Rodrigues. Responsabilidade civil do Estado por atos dos agentes dos poderes Legislativo, Executivo e Judiciário. Campinas: Bookseller, 2001. t.1.

BANDEIRA DE MELLO, Celso Antônio. Curso de direito administrativo. 16. ed. São Paulo: Malheiros. 2003.

BORGES, José Souto Maior. O princípio da segurança jurídica na criação e aplicação do tributo. Revista Diálogo Jurídico, Salvador, n. 11, p. 1-6, fev. 2002.

BRASIL Constituição federal. Disponível em: <www.planalto.gov.br/ccivil_ 03/Constituicao/Constituicao.htm>. Acesso em: 26 fev. 2011.

. Supremo Tribunal Federal. Informativo do STF, relator ministro Gilmar Mendes, n. 343; MS n. 22357/DF, DJU, Brasília, 24 maio 2004. Disponível em: www.stf.jus.br>. Acesso em: 26. fev. 2011.

. Supremo Tribunal Federal. Informativo do STF. Relator ministro Gilmar Mendes n. 231, MS 24268/MG, 15 mar. 2003. Disponível em: <www.stf. jus.br//arquivo/informativo/documento/informativo231.htm>. Acesso em: 26 fev. 2011.

. Supremo Tribunal Federal. MC no 2.900-RS. 2aㅡ Turma, relator ministro Gilmar Mendes, 8 mar. 2003. Disponível em: <www.stf.jus.br >. Acesso em: 26 fev. 2011.

CAHALI, Yussef Said. Responsabilidade civil do Estado. São Paulo: Revista dos Tribunais, 1982. 
CALMÈS, Sylvia. Du principe de protection de la confiance légitime em droitsallemand, communautaire et français. Paris: Dalloz, 2001.

CARVALHO, Raquel. O direito à informação administrativa procedimental. Porto: Universidade Católica, 1999.

CASTILLO BLANCO, Frederico. La protección de confianza en el derecho administrativo. Madrid: Marcial Pons, 1988.

CAVALCANTI, Amaro. Responsabilidade civil do Estado. Rio de Janeiro: Borsoi, 1957. t.1.

CERDA, Clara Leonora Szczaranski. Responsabilidad extracontractual del Estado. Revista de Derecho - Derecho Administrativo, n. 8. ago. 2003. Disponível em: <www.cde.cl/wps/wcm/connect/.../2.pdf?MOD=AJPERES>. Acesso em: 14 fev. 2011.

COLOMBIA. Corte Constitucional de Colombia. Sentencia T-472/09. Accion de tutela contra actuaciones de autoridades de policia. Disponível em: $<w w w$. corteconstitucional.gov.co/relatoria/2009/T-472-09.htm>. Acesso em: 26 fev. 2011.

CORREIA, Maria Lúcia C.A. Amaral Pinto. Responsabilidade do Estado e dever de indenizar do legislador. Coimbra: Coimbra, 1998.

CRETELLA JÚNIOR, José. O Estado e a obrigação de indenizar. Rio de Janeiro: Forense, 1998.

DI PIETRO, Maria Sylvia Zanella. Os princípios da proteção à confiança, da segurança jurídica e da boa-fé na anulação do ato administrativo. Fórum Administrativo. Direito Público - F.A., Belo Horizonte, ano 9, n. 100, p. 155-166, jun. 2009.

GANDINI, João Agnaldo Donizeti. Responsabilidade do Estado em caso de falência de concessionário. Campinas: Minelli, 2003.

GARCIA LUENGO, Javier. El principio de protección de la confianza em el derecho administrativo. Madrid: Civitas, 2002.

GORDILLO, Augustín. Tratado de derecho administrativo: la defesa del usuário y del administrado. 5. ed. Belo Horizonte: Del Rey, 2003. t. 1.

GUERRA, Evandro Martins; MIARI, Áira Lages. O processo administrativo e o princípio da segurança jurídica. Fórum Administrativo. Direito Público - F.A., Belo Horizonte, ano 6, n. 59, p. 6662-6679, jan. 2006. 
LOSSO, Marcelo Ribeiro. O princípio da proteção à confiança nas relações contratuais entre o Estado e o agente privado. Dissertação (mestrado) - Direito Econômico e Social, Pontifícia Universidade Católica do Paraná, Curitiba, 2008.

MAFFINI, Rafael da Cás. Princípio da proteção substancial da confiança no direito administrativo brasileiro. Tese (doutorado) - Faculdade de Direito, Universidade Federal do Rio Grande do Sul, Porto Alegre, 2005.

MARTINS, Ives Gandra da Silva. O Supremo e a segurança jurídica. Revista Consulex, Brasília, ano 11, n. 259, p. 21, 31 out. 2007.

MARTINS, Raphael Magalhães. O princípio da confiança legítima e o enunciado n. 362 da IV jornada de direito civil. Revista CEJ, Brasília, ano 12, n. 40, p. 11-19, jan./mar. 2008.

MEDAUAR, Odete. Direito administrativo moderno. 11. ed. São Paulo: Revista dos Tribunais, 2009.

MEIRELLES, Hely Lopes. Direito administrativo brasileiro. 36. ed. São Paulo: Malheiros, 2010.

MENDES, Gilmar Ferreira; COELHO, Inocêncio Mártires; BRANCO, Paulo Gustavo Gonet. Curso de direito constitucional. São Paulo: Saraiva, 2007.

MENEZES CORDEIRO, António Manuel da Rocha e. Da boa-fé no direito civil. Coimbra: Almedina, 2001. (Teses)

MIRANDA, Jorge. Manual de direito constitucional: direitos fundamentais. 3. ed. Coimbra: Coimbra, 2000. t. 4.

OLIVEIRA, Fernando Albino de. Os tribunais e o princípio da segurança jurídica. Revista Consulex, Brasília, ano 12, n. 265, p. 56-57, 31 jan. 2008.

PALACIO PALACIO, Jorge Iván. Principio de confianza legítima en la jurisprudencia de la corte constitucional. Disponível em: $<$ http://iusconstifil.blogspot. com/2009/09/principio-de-confianza-legitima-en-la.html>. Acesso em: 26 fev. 2011.

SANZ RUBIALES, Iñigo. El principio de confianza legítima, limitador del poder normativo comunitário. Disponível em: <www.cepc.es/rap/Publicaciones/Revistas/4/RDC_007_091.pdf>. Acesso em: 26 fev. 2011.

SILVA, Almiro do Couto e. O princípio da segurança jurídica (proteção à confiança) no direito público brasileiro e o direito da administração pública de anular seus próprios atos administrativos: o prazo decadencial do art. 54 da 
LEI DE PROCESSO Administrativo da União. Lei no 9.784/99. Revista Brasileira de Direito Público - RBDP, Belo Horizonte, ano 2, n. 6, p. 7-59, jul./set. 2004.

SCHONBERG, Soren J. Legitimate expectations in administrative law. Oxford: Oxford, 2000.

STEIN, Torstein. A segurança jurídica na ordem legal da República Federal da Alemanha. Cadernos Adenauer, Rio de Janeiro, n. 3, 2000. (Acesso à Justiça e Cidadania. Fundação Konrad Adenauer Stiftung).

VAINER, Bruno Zilberman. Aspectos básicos da segurança jurídica. Revista de Direito Constitucional e Internacional, São Paulo, ano 14, n. 56, p. 5-26, jul./set. 2006. 